\title{
Effects of Inappropriate Acetylsalicylic Acid Use on Non-fatal Bleedings
}

\author{
Uygunsuz Asetil Salisilik Asit Kullanımının Ölümcül Olmayan Kanamalar Üzerine Etkisi \\ ๑ Mustafa Öztürk, ๑ Oğuzhan Ekrem Turan* \\ University of Health Sciences, Erzurum Training and Research Hospital, Clinic of Cardiology, Erzurum, Turkey \\ ${ }^{*}$ Karadeniz Technical University Faculty of Medicine, Department of Cardiology, Trabzon, Turkey
}

\section{Abstract}

\begin{abstract}
Aim: This study aims to assess of using asetylsalicyclic acid (ASA) on non-fatal major and minor bleeding events in patients with inappropriate, primary and secondary prevention groups.
\end{abstract}

Methods: Nine thousand, six hundred and fifty-one patients were screened within a one-year period. Patients using ASA for primary and secondary prevention were recorded. A total of 736 patients using ASA were divided into three groups as inappropriate, appropriate primary and secondary prevention.

Results: One hundred and two (14\%) patients were using ASA inappropriately. The duration of ASA use was 82.9 \pm 71.3 months. Thirteen (1.8\%) major (11 gastrointestinal, one intraocular, one intracranial) and 29 minor (3.9\%) bleedings had occurred. Eleven $(2.5 \%)$ major bleeding events had occurred in secondary prevention group and one $(0.5 \%)$ in appropriate and one $(1 \%)$ in inappropriate primary prevention group $(p=0.16)$. Nineteen $(4.4 \%)$ and $10(5.1 \%)$ minor bleeding events were seen in appropriate and secondary prevention groups, respectively and there was no minor bleeding event occurred in inappropriate primary prevention group $(p=0.078)$.

Conclusion: Our study showed that inappropriate ASA use did not increase the risk of non-fatal major and minor bleeding events. It may be reasonable to consider that patients without a history of occlusive vascular disease are less prone to nonfatal bleeding events compared to those with occlusive vascular disease.

Keywords: Acetylsalicylic acid, primary prevention, non-fatal bleeding
Öz

Amaç: Bu çalışmada kardiyovasküler hastalıklardan birincil korumada uygun, uygunsuz veya ikincil korumada asetil salisilik asit (ASA) kullanımının ölümcül olmayan majör ve minör kanamalar üzerine etkisinin araştırılması amaçlanmıştır.

Yöntemler: Bir yıllık süreçte 9651 hasta gözlemlendi ve birincil ve ikincil koruma için ASA kullananlar kaydedildi. Toplam 736 ASA kullanan hasta çalışmaya dahil edildi. Hastalar üç gruba ayrıldı: Birincil koruma için uygun ve uygunsuz ve sekonder koruma için ASA kullanan hastalar.

Bulgular: Yüz iki (\%14) katılımcıda uygunsuz ASA kullanımı tespit edildi. Toplam ASA kullanım süresi $82,9 \pm 71,3$ ay idi. Bu süreçte total $13(\% 1,8)$ majör $(11$ gastrointestinal, bir göz içi, bir kafa içi) ve $29(\% 2,9)$ minör kanama oluşmuştur. On bir $(\% 2,5)$ majör kanama ikincil koruma grubunda, bir $(\% 0,5)$ uygun ASA kullanan grupta, bir (\%1) uygunsuz ASA kullanan grupta gözlemlenmiştir $(p=0,16)$. Minör kanamaların 19'u uygun ASA kullanan ve 10'u ikincil korumada ASA kullanan hastalarda gözlenmiştir ( $p=0,078)$. Uygunsuz ASA kullanan grupta minör kanama gözlemlenmemiştir.

Sonuç: Çalışmamız uygunsuz ASA kullanımının ölümcül olmayan majör ve minör kanama oranını artırmadığını göstermiştir. ASA kullanan, tıkayıcı damar hastalığı olanlara göre tıkayıc damar hastalığı olmayanların kanamaya meyillerinin daha az olduğunu söylemek makul olabilir.

Anahtar Sözcükler: Asetil salisilik asit, birincil koruma, ölümcül olmayan kanama

Address for Correspondence/Yazışma Adresi: Mustafa Öztürk, University of Health Sciences, Erzurum Training and Research Hospital, Clinic of Cardiology, Erzurum, Turkey E-mail: mozturk81@yahoo.com ORCID: orcid.org/0000-0002-8191-6576 


\section{Introduction}

Cardiovascular diseases (CVDs), which include coronary, cerebrovascular, and peripheral artery diseases, are the leading cause of death in developed countries (1). Similar with the world's rate, these serious vascular events are responsible for approximately $40 \%$ of deaths in Turkey (2). Primary prevention plays a major role in reducing CVD burden. Antithrombotic therapy represents the cornerstone of preventive therapy. Acetylsalicylic acid (ASA), a well known antithrombotic agent, is one of the most widely used However, its place in primary and secondary prevention is again being questioned (3).

It has been reported that long-term antiplatelet therapy prevented approximately $25 \%$ of serious vascular events [fatal or non-fatal myocardial infarction (MI) and/ or stroke] in patients with a history of occlusive event (4). Despite its beneficial effects, gastrointestinal (GI) bleeding risk increases 1.5 to two fold within 5 years and this serious event is independently related to mortality and ischemic complications in patients with acute coronary syndrome $(5,6)$. And also, in this patient group who developed vascular events, major bleeding event rates reach 3.5-4\% annually. Moreover, minor bleeding is more frequently reported with the rates of $4 \%-23 \%$ per year $(7,8)$. However, the benefits of ASA use outweigh the harms in the secondary prevention side. For primary prevention, ASA is recommended for those with moderate to high 10-year CVD risk (9). The net benefits of ASA use in primary prevention is less clear than in secondary prevention because it is hard to estimate continuously the risk for vascular disease or bleeding events. Primary prevention trials showed that ASA use reduced the relative risk for non-fatal $\mathrm{MI}$ and stroke by $17 \%$ and $14 \%$, respectively but no significant effect on all causes mortality has been reported (10). Also in 5070 years old men and women who had a 10-year CVD risk over $10 \%$, serious Gl bleeding events (men 2.6-3.14 $\%$, women $1.84-2.3 \%$ ) are more frequently seen than non-fatal MI (men 1.59-2.86\%, women 1-1.52\%) and non-fatal ischeamic stroke (men $0.66-0.92 \%$, women 1.16-1.44\%), nevertheless in patients receiving ASA high levels of Gl bleeding does not prevent net survival gain of 3.3-6 years. Moreover, it has been reported that patients on very low-dose ASA therapy $(\leq 100 \mathrm{mg}$ per day) had 1.58-fold and 1.27-fold increased 10-year major Gl bleeding and intracranial hemorrhage risks, respectively (11). Most of trials and meta-analysis in primary prevention area largely ignored minor bleeding risks but this minor effect could cause cessation of medication and underestimation of the clear benefits or hazards. Besides an important group of patients who takes ASA inappropriately has been recently well described (12). It was seen that more than one in 10 patients used ASA inappropriately. Bleeding outcomes in this group of patients are still unclear. Therefore, we aimed to compare the major and minor bleeding events between patients using ASA for primary prevention and secondary prevention appropriately and inappropriately.

\section{Methods}

\section{Study Population}

The study was a cross-sectional study. Population of this study was prospectively recruited from our cardiology outpatient clinics between January 2015 and January 2016. A total of 9651 patients were identified within the period of one year. Patient who were using ASA for primary and secondary prevention were recorded consecutively. A total of 835 patients were identified. Ninety-nine ASA users, who were re-recorded were excluded. A total of 736 patients were included the study. Data on reasons for ASA use, dosage, duration of therapy and habit of regular or irregular drug use were obtained via patient interview and individual answers were recorded. Age, gender, weight, height, and systolic and diastolic blood pressure were also recorded. Medical history including hypertension, diabetes mellitus, dyslipidemia, smoking status, coronary artery disease described as a history of $\mathrm{Ml}$ and/or percutaneous coronary intervention and/ or coronary artery bypass surgery, valvular heart disease, prior heart valve repair and/or replacement, and periphery artery disease were recorded. Patient's medications were also recorded. The total number of drugs, proton pump inhibitors (PPI), P2Y12 receptor antagonists, and oral anticoagulants were recorded. Data on patients using nonsteroidal anti-inflammatory drugs (NSAIDs) were obtained via electronic medical records. 10-year CVD risk was calculated with the EuroSCORE system (8). Patients with a 10-year CVD risk of $10 \%$ and above were considered appropriate user and those with below $10 \%$ were considered inappropriate user for primary prevention. Then, the patients were categorized into three groups as inappropriate, appropriate primary and secondary prevention groups. The study was approved by the University of Health Sciences, Erzurum Regional Training and Research Hospital (no: 37732058-514.10) (18/06/2018).

\section{Laboratory Parameters}

Patients' laboratory data were retrieved from the electronic medical records. Serum total cholesterol, triglyceride, high-density lipoprotein (HDL), low-density lipoprotein (LDL), lowest and highest hemoglobin and the time interval between lowest and highest hemoglobin levels, and platelet count were collected and recorded. 


\section{Bleeding Events Data}

Bleeding events were identified based on the Bleeding Academic Research Consortium (BARC) definition (13). For hemorrhagic events, the patients were asked if any bleeding event had occurred while using ASA. If said yes, the events were scored according to the BARC criteria. BARC type 1 was accepted as minor bleeding and BARC $2,3,4,5$ as major bleeding. Hemoglobin drop of 3 to $<5 \mathrm{~g} /$ $\mathrm{dL}$ and transfusion with overt bleeding was cathegorized as BARC 3a and hemoglobin drop of $<5 \mathrm{~g} / \mathrm{dL}$ with overt bleeding requiring surgical intervention for control as BARC 3b. If it was not occurred in a short time interval, this was not considered bleeding event. Men with a hemoglobin level below $13 \mathrm{~g} / \mathrm{dL}$ and women with a hemoglobin level below $12 \mathrm{~g} / \mathrm{dL}$ were considered having anemia in accordance with the recommendations of the World Health Organization (14).

\section{Statistical Analysis}

Statistical analyses were performed using the SPSS software (Version 14.0, SPSS, Inc., Chicago, IL). Continuous variables were presented as mean \pm standard deviation, and categorical variables were presented as percentages. The variables were investigated using visual (histograms, probability plots) and analytical methods (KolmogorovSmirnov/Shapiro-Wilk test) to determine whether or not the data were normally distributed. Total cholesterol, highest hemoglobin and lowest hemoglobin levels were found to be normally distributed. One-way ANOVA was used to compare these parameters among the prevention (inappropriate primary/appropriate primary/secondary) groups. Levene's test was used to assess the homogeneity of the variance. When overall significance was observed, pairwise post-hoc testing was performed using Tukey's test with Bonferroni correction. Age, ASA dose and duration of treatment, systolic and diastolic blood pressure, triglyceride, HDL and LDL levels, platelet count, height, weight, body mass index (BMI), and EuroSCORE variables were found to be not normally distributed. The Kruskal-Wallis test was conducted to compare these parameters among the prevention (inappropriate primary/ appropriate primary/secondary) groups. The MannWhitney $U$ test was performed to test the significance of pairwise differences using Bonferroni correction to adjust for multiple comparisons. The proportions of patients with inappropriate/appropriate primary and secondary prevention groups were presented by gender, smoking status, hypertension, diabetes mellitus, dyslipidemia, coronary artery disease, habit of regular or irregular ASA use. Ace-ARB inhibitors, b-blocker, calcium channel blocker, statin, NSAID, PPI, P2Y12 receptor antagonist, oral anticoagulant use and BARC data were compared with using cross tabulations. The chi-square test or Fisher's exact test (when chi-square test assumptions do not hold due to low expected cell counts) was used to compare these proportions in different groups.

\section{Results}

Baseline data of all groups are demonstrated in Table 1. There was a significant difference in age between the three groups (mean: $56.2 \pm 8.8,73.1 \pm 7.6$ and $64.6 \pm 10.4$, respectively) $(p<0.001)$. The rate of female gender was found to be higher in appropriate use for primary prevention group than in other groups $(57.3 \%, 72.1 \%$ and $25.2 \%$, respectively) and the rate of male gender was significantly higher in secondary prevention group $(42.7 \%$, $37.9 \%$ and $74.8 \%$, respectively) $(p<0.001)$. The BMI was found to be higher in appropriate for primary prevention group than in the other groups $(29.3 \pm 5.8,27.8 \pm 4.8$ and $27.9 \pm 4.5$, respectively) $(p=0.032)$. The rate of irregular ASA use was significantly higher in inappropriate group than in other groups $(12.6 \%, 7.1 \%$ and $3.7 \%$, respectively) $(p=0.002)$. The rate of irregular ASA use was significantly higher in inappropriate group than in other groups. There was no significant difference in the duration of ASA therapy between the groups $(65 \pm 67.6,83.1 \pm 71.2$ and $78.4 \pm 61.9$ months, respectively) $(p=0.075)$. The rate of diabetes mellitus was found to be higher in secondary prevention group than in other groups $(25.2 \%, 26.3 \%, 35.4 \%$, respectively) ( $p=0.02$ ). Hypertension was more common in inappropriate and appropriate prevention groups than in secondary prevention group $(71.8 \%, 75.8 \%$ and $66.4 \%$, respectively) $(p=0.05)$. The rate of patients with dyslipidemia in secondary prevention group was significantly higher than in others $(25.2 \%, 30.8 \%$ and $53.7 \%$, respectively) $(p<0.001)$. In the appropriate primary prevention group, there were 42 atrial fibrillation (AF) patients and the mean Chads2 vasc score was $3.09 \pm 0.93$ and HAS-BLED score was $3 \pm 1.67$. Having AF had no statistically significant effect on major and minor bleeding events $(p=0.773$ and $p=0.290$, respectively). One patient in this group had intracranial hemorrhage requiring hospitalization and transfusion but not surgery. In addition, three patients in this group had minor bleeding event recorded as urinary tract bleeding, hemoptysis and epistaxis requiring only discontinuation of ASA and no hospitalization and/or any additional therapy. Appropriate primary prevention group had significantly lower smoking rate; other groups were similar $(20.4 \%$, $10.1 \%$ and $18.9 \%$, respectively) ( $p=0.013$ ). Systolic blood pressure levels in appropriate group were found to be higher than in inappropriate group but not in the secondary group and diastolic blood pressure levels in all the three groups were found to be similar (SBP-127.4 $\pm 19.2,133.2 \pm 23.1$ and $129.4 \pm 20.4 \mathrm{mmHg} ; \mathrm{p}=0.041$ and DBP-79.2 \pm 12.5 , $78.6 \pm 13.3$ and $78.4 \pm 11.7 \mathrm{mmHg}$, respectively; $p=0.85$ ). 
The rate of angiotensin-receptor blockers use was similar between the three groups (54.4\%, 51.3\% and 48.7\%, respectively) ( $p=0.567)$. There was a significant difference in the rate of B-blocker use between the three groups and the highest value was in secondary prevention group $(47.8 \%, 63.5 \%$ and $75.1 \%$, respectively) $(p<0.001)$. Calcium channel blocker (dihydropyridine/non dihydropyridine) use was found to be similar for all groups $(24.4 \%, 17.5 \%$ and $17.8 \%$, respectively) ( $p=0.306)$. The rate of patients using statin was higher in secondary prevention group than in the others but there was no statistically significant difference between inappropriate and appropriate groups (20\%, $25.7 \%$ and $52.4 \%$, respectively) $(p<0.001)$. There was no patient taking P2Y12 receptor antagonists in inappropriate primary prevention group but the rates of patients using P2Y12 receptor antagonists in appropriate and secondary prevention groups were 1.5\% and $17.9 \%$, respectively $(p<0.001)$. There was only one patient using dual antiplatelet therapy when Gl bleeding event had occurred. Concomitant use of P2Y12 receptor blockers had no effect on major or GI bleeding events. $(p=0.838)$. Seven minor bleeding events were observed in 81 patients on dual antiplatelet therapy with $\mathrm{P} 2 \mathrm{Y} 12$ and. Six of these patients were in the secondary prevention group and one in the appropriate group. Concomitant use of P2Y12 receptor blockers had no effect on the development of minor bleeding events in any patient $(p=0.24)$. Only nine patients in secondary prevention group were on warfarin therapy. Three patients in appropriate and one in secondary prevention group were using new oral anticoagulant. All those oral anticoagulant patients had no adverse event. The rate of patients using PPI was found to be higher in appropriate primary prevention group than in the others but there was no significant difference between the secondary and inappropriate primary prevention groups $(41.9 \%$, $57.4 \%$ and $46.6 \%$, respectively) ( $p=0.044)$. There was no significant difference in the incidence of major, GI or minor bleeding events between the groups $(p=0.377, p=0.206$ and $p=0.443$, respectively). The proportion of patients using NSAIDs was significantly higher in inappropriate and appropriate primary prevention groups than in secondary prevention group $(60.7 \%, 54.9 \%$ and $44.5 \%$, respectively)

\begin{tabular}{|c|c|c|c|c|c|}
\hline * $\neq$ & $\begin{array}{l}\text { Inappropriate use } \\
(n=102)\end{array}$ & $\begin{array}{l}\text { Appropriate primary } \\
\text { prevention } \\
\text { use }(n=198)\end{array}$ & $\begin{array}{l}\text { Secondary } \\
\text { prevention use } \\
(n=436)\end{array}$ & Test value & $\mathbf{p}$ \\
\hline Age (years) & $56.2 \pm 8.8$ & $73.1 \pm 7.6^{\ddagger}$ & $64.6 \pm 10.4^{*, \neq}$ & $\mathrm{F}=114.197$ & $<0.001$ \\
\hline Women, n (\%) & $58(57.3)$ & $123(72.1)$ & $110(25.2)$ & $\chi^{2}=93.079$ & $<0.001$ \\
\hline BMI $\left(\mathrm{kg} / \mathrm{m}^{2}\right)$ & $29.3 \pm 5.8$ & $27.8 \pm 4.8$ & $27.9 \pm 4.5$ & $F=3.470$ & 0.032 \\
\hline Duration of acetylsalicylic acid usage (month) & $65 \pm 67.6$ & $83.1 \pm 71.2$ & $78.4 \pm 61.9$ & $F=2.596$ & 0.075 \\
\hline Regular acetylsalicylic acid usage, n (\%) & $90(87.4)$ & $183(92.4)$ & $420(96.3)$ & $\chi^{2}=13.136$ & $<0.001$ \\
\hline Diabetes, n (\%) & $26(25.2)$ & $52(26.3)$ & $154(35.4)$ & $\chi^{2}=7.453$ & 0.024 \\
\hline Hypertension, n (\%) & $74(71.8)$ & $150(75.8)$ & $289(66.4)$ & $\chi^{2}=5.858$ & 0.05 \\
\hline Dyslipidemia, n (\%) & $26(25.2)$ & $61(30.8)$ & $233(53.7)$ & $\chi^{2}=45.261$ & $<0.001$ \\
\hline Tobacco use, n (\%) & $21(20.4)$ & $20(10.1)$ & $82(18.9)$ & $\chi^{2}=8.692$ & 0.013 \\
\hline SBP $(\mathrm{mmHg})$ & $127.4 \pm 19.2$ & $133.2 \pm 23.1$ & $129.4 \pm 20.4$ & $F=3.204$ & 0.041 \\
\hline DBP $(\mathrm{mmHg})$ & $79.2 \pm 12.5$ & $78.6 \pm 13.3$ & $78.4 \pm 11.7$ & $F=0.163$ & 0.85 \\
\hline RAS blocker, n (\%) & $49(54.4)$ & $97(51.3)$ & $199(48.7)$ & $\chi^{2}=1.133$ & 0.567 \\
\hline B blocker, n (\%) & $43(47.8)$ & $120(63.5)$ & $308(75.1)$ & $\chi^{2}=28.365$ & $<0.001$ \\
\hline CCB, n (\%) & $22(24.4)$ & $33(17.5)$ & $73(17.8)$ & $\chi^{2}=2.366$ & 0.306 \\
\hline Statin, n (\%) & $13(20)$ & $39(25.7)$ & $164(52.4)$ & $\chi^{2}=43.512$ & $<0.001$ \\
\hline P2Y12 receptor blocker, n (\%) & 0 & $3(1.5)$ & $78(17.9)$ & $\chi^{2}=52.248$ & $<0.001$ \\
\hline OAC, n (\%) & 0 & $3(1.5)$ & $10(2.3)$ & $\chi^{2}=2.626$ & 0.269 \\
\hline Proton pump inhibitor, $\mathbf{n}(\%)$ & $26(41.9)$ & $82(57.7)$ & $139(46.6)$ & $\chi^{2}=6.238$ & 0.044 \\
\hline NSAID, n (\%) & $37(60.7)$ & $79(55.2)$ & $130(44.5)$ & $\chi^{2}=7.819$ & 0.020 \\
\hline Total drug count & $3.7 \pm 1.7$ & $5.2 \pm 2.5$ & $5.5 \pm 2.2$ & $F=16.219$ & $<0.001$ \\
\hline \multicolumn{6}{|c|}{$\begin{array}{l}\text { BMI: Body mass index, SBP: Systolic blood pressure, DBP: Diastolic blood pressure, RAS: Renin angiotensin/aldosterone system, CCB: Calchium channel blocker, OAC: Oral } \\
\text { anticoagulant, NSAID: Non steroid antinflamatory drug } \\
\text { Continuous data are shown as mean } \pm \text { standard deviation, and categorical data are shown as percentages. Bold } p \text { values for ANOVA p<0.017 were excepted significant } \\
\text { and for chi-square } p<0.05 \text { were excepted significant }\end{array}$} \\
\hline
\end{tabular}


$(p=0.022)$. NSAID use had no significant effect on the development of major, $\mathrm{Gl}$ or minor bleeding events ( $p=0.292, p=0.163$ and 0.353 , respectively). The total number of the drugs used was higher in secondary and appropriate primary prevention groups than in inappropriate primary prevention group $(3.7 \pm 1.7,5.2 \pm 2.5$ and $5.5 \pm 2.2$, respectively) $(p<0.001)$. There was no difference in the total number of drugs between secondary and appropriate primary prevention groups $(p=0.6)$. The total number of drugs used had no significant effect on the development of major bleeding ( $p=0.268$ and $p=0.174$, respectively) and minor bleeding events in appropriate and secondary prevention groups ( $p=0.491$ and $p=0.564$, respectively).

\begin{tabular}{|c|c|c|c|c|}
\hline \multirow{2}{*}{$\begin{array}{l}\text { Inappropriate use of } \\
\text { acetylsalicylic acid cause }\end{array}$} & \multicolumn{4}{|c|}{ EuroscoRE\% } \\
\hline & n (\%) & Mean \pm SD & Min & Max \\
\hline HT & $36(35.3)$ & $4.67 \pm 2.68$ & 1 & 9 \\
\hline $\begin{array}{l}\text { Normal coronary } \\
\text { angiography result }\end{array}$ & $27(26.5)$ & $4.41 \pm 2.50$ & 0 & 8 \\
\hline DM & $12(11.8)$ & $5.67 \pm 2.15$ & 2 & 9 \\
\hline Valvular heart disease & $10(9.8)$ & $2.60 \pm 2.27$ & 0 & 7 \\
\hline Dysrhytmia & $9(8.8)$ & $4.78 \pm 1.92$ & 1 & 7 \\
\hline$H T+D M$ & $7(6.9)$ & $5.86 \pm 2.19$ & 2 & 9 \\
\hline Heart failure & $7(6.9)$ & $6.57 \pm 2.44$ & 2 & 9 \\
\hline Self usage & $6(5.9)$ & $2.83 \pm 2.79$ & 0 & 8 \\
\hline Dyslipidemia & $4(3.9)$ & $5.75 \pm 3.94$ & 1 & 9 \\
\hline HT + dyslipidemia & $3(2.9)$ & $4.67 \pm 4.04$ & 1 & 9 \\
\hline \multicolumn{5}{|c|}{$\begin{array}{l}\text { DM: Diabetes mellitus, HT: Hypertension, SD: Standard deviation, Min: Minimum, } \\
\text { Max: Maximum, } n \text { : Number } \\
\text { Data are shown as mean } \pm \text { standard deviation, and categorical data are shown } \\
\text { as percentages }(n=102)\end{array}$} \\
\hline
\end{tabular}

The reasons for inappropriate ASA use and EuroSCORE values are demonstrated in Table 2.

The rate of patients with inappropriate ASA use was found to be $14 \%$ in the study population. The mean EuroSCORE value in inappropriate and appropriate primary prevention groups was $4.6 \pm 2.6$ and $13.2 \pm 5.3$, respectively. The main reason for inappropriate ASA use was hypertension in $35.3 \%$ of patients. Twenty-six-point five percent of those using ASA inappropriately were receiving ASA therapy after a coronary angiography procedure even though their results were normal. ASA was prescribed by healthcare professionals in $94.1 \%$; only $5.9 \%$ were taking ASA on their own. Diabetes mellitus $(11.8 \%)$, asymptomatic mild valvular heart disease (9.8\%), dysrhythmia (8.8\%), hypertension plus diabetes mellitus (6.9\%), non-ischeamic heart failure (6.9\%), dyslipidemia (3.9\%), and hypertension plus dyslipidemia (2.9\%) were the other reasons for prescription of inappropriate ASA therapy. Laboratory data are demonstrated in Table 3. Total cholesterol, triglyceride, HDL and LDL values were found to be similar between the groups. ANOVA analysis revealed statistically significant differences in highest, latest and lowest hemoglobin values between the groups $(p<0.001$ for all). The highest hemoglobin value in secondary prevention group was found to be higher than in appropriate primary prevention group $(14.2 \pm 1.5$ vs $13.4 \pm 1.5)(p<0.001)$, but there was no difference between appropriate and inappropriate primary prevention groups $(13.4 \pm 1.5$ vs $13.6 \pm 1.8)(p=0.38)$. The lowest hemoglobin value in appropriate primary prevention group was found to be lower than in secondary prevention group $(12 \pm 1.7$ vs $12.8 \pm 1.8)(p<0.001)$, but there was no significance difference between appropriate and inappropriate primary prevention groups $(12.5 \pm 2.2$ vs $12 \pm 1.7)(p=0.32)$.

Table 3. Laboratory data for both groups

\begin{tabular}{|c|c|c|c|c|c|}
\hline$*_{f}$ & $\begin{array}{l}\text { Inappropriate use } \\
(\mathrm{n}=102)\end{array}$ & $\begin{array}{l}\text { Appropriate primary } \\
\text { prevention use } \\
(\mathrm{n}=198)\end{array}$ & $\begin{array}{l}\text { Secondary } \\
\text { prevention use } \\
(n=436)\end{array}$ & Test value & $\mathbf{p}$ \\
\hline Total cholesterol (mg/dL) & $192.2 \pm 48.9$ & $199.9 \pm 58.9$ & $202.4 \pm 51.3$ & $F=0.913$ & $p=0.4$ \\
\hline Triglycerides (mg/dL) & $148.5 \pm 77.4$ & $146.6 \pm 73.7$ & $163.2 \pm 116.2$ & $F=1.32$ & $p=0.268$ \\
\hline $\mathrm{HDL}(\mathrm{mg} / \mathrm{dL})$ & $51.2 \pm 15.9$ & $53.8 \pm 16.1$ & $50.2 \pm 14.2$ & $F=2.329$ & $p=0.099$ \\
\hline $\mathrm{LDL}(\mathrm{mg} / \mathrm{dL})$ & $114.1 \pm 34.4$ & $113.7 \pm 39.7$ & $117.3 \pm 38.2$ & $F=0.448$ & $p=0.639$ \\
\hline Highest hemoglobin $(\mathrm{g} / \mathrm{dL})$ & $13.6 \pm 1.8$ & $13.4 \pm 1.5$ & $14.2 \pm 1.5$ & $F=16.669$ & $p<0.001$ \\
\hline Latest hemoglobin $(\mathrm{g} / \mathrm{dL})$ & $12.9 \pm 1.9$ & $12.6 \pm 1.6$ & $13.3 \pm 1.7$ & $F=11.209$ & $p<0.001$ \\
\hline Lowest hemoglobin $(\mathrm{g} / \mathrm{dL})$ & $12.5 \pm 2.2$ & $12 \pm 1.7$ & $12.8 \pm 1.8$ & $F=9.767$ & $p<0.001$ \\
\hline Delta hemoglobin & $1.1 \pm 1.3$ & $1.3 \pm 1.2$ & $1.4 \pm 1.3$ & $F=1.311$ & $p=0.27$ \\
\hline Duration of hemoglobin changes (mounth) & $19.5 \pm 20.2$ & $23.6 \pm 22.1$ & $23.7 \pm 20.4$ & $F=1.272$ & $p=0.281$ \\
\hline Platelet count $(\mathrm{g} / \mathrm{dL})$ & $232.2 \pm 69.9$ & $219.9 \pm 64.4$ & $220 \pm 66.5$ & $F=1.079$ & $p=0.341$ \\
\hline
\end{tabular}


The total time interval between the lowest and highest hemoglobin value was $23 \pm 20.8$ months. There was no difference in time interval between the groups $(p=0.281)$. The changes between highest and lowest hemoglobin (delta hemoglobin) values were similar between the three groups (1.1 $\pm 1.3,1.3 \pm 1.2$ and $1.4 \pm 1.3$, respectively) $(p=0.27)$. There was no statistically significant difference in platelet count between the three groups $(232.2 \pm 69.9$, $219.9 \pm 64.4$ and $220 \pm 66.5$, respectively) ( $p=0.34$ ). Anaemia rates for women were found to be similar between the three groups [21 (45.6\%), $56(50 \%)$ and $56(50.9 \%)$, respectively $(p=0.48)]$, but for men, the rates were higher in approppriate primary and secondary prevention groups than in inappropriate use group [10 $(22.7 \%), 36(38 \%), 104(31.9 \%)$ respectively $(p=0.018)]$. The most recent hemoglobin values were found to be higher in secondary prevention group than in appropriate primary prevention group $(13.3 \pm 1.7$ vs $12.6 \pm 1.6)$ $(p<0.001)$, but there was no difference between appropriate and inappropriate primary prevention groups $(12.9 \pm 1.9$ vs $12.6 \pm 1.6)(p=0.38)$. Data on bleeding events is demonstrated in Table 4. A total of $13(1.8 \%)$ major and 29 (3.9\%) minor bleeding events had occurred in a total $82.9 \pm 71.3$ months of ASA therapy. Eleven major bleedings were recorded as GI bleeding which require blood transfusion defined as BARC 3a. Also, two major bleedings recorded as intracranial bleeding which required surgical intervention for control described as BARC 3b. A total $11(2.5 \%)$ major bleeding events had occurred in secondary prevention group and one $(0.5 \%)$ in appropriate and one (1\%) in inappropriate primary prevention groups, but these rates were not statistically significant $(p=0.16)$. Only one patient in secondary prevention group with $\mathrm{Gl}$ bleeding event was using P2Y12. There was no patient using oral anticoagulant therapy at the time of major bleeding event. Ten (2.3\%) Gl bleeding had occurred in secondary prevention group and one (1\%) in inappropriate primary prevention group but the number of events did not reach statistical significance $(p=0.079)$. Twenty-nine minor bleeding events were recorded with hemoptysis, ecchymosis, petechiae, hemorrhoid, epistaxis, urinary tract hemorrhage. Those minor hemorrhages did not require hospitalization or treatment by a healthcare professional, but resulted in self-discontinuation of medical therapy by the patient. The number of minor bleeding events did not have statistically significance $(p=0.078)$. Six patients with minor bleeding event in secondary group and one patient in appropriate prevention group were taking dual antiplatelet therapy with P2Y12 receptor blocker and this concomitant usage had no significant effect on the development of minor bleeding events $(p=0.24)$.

\section{Discussion}

The results of the present study showed that in a total $82.9 \pm 71.3$ months of ASA therapy, ASA did not increase major bleeding events in inappropriate group than in appropriate and/or secondary prevention groups. Our data showed that there was no patient having a minor bleeding event in inappropriate use group in this time interval. To the best of our knowledge, there is no direct comparison of these three groups in the literature. Majority of data in clinical trials included appropriate primary and secondary prevention groups. Patients using ASA inappropriately were mostly ignored and their bleeding outcomes are not clear. Antiplatelet therapy may not be harmful for patients using ASA inappropriately or appropriately for primary prevention.

Recently, a large cohort study showed that inappropriate use of ASA rate exceeded $11.6 \%$ in the U.S population. This rate decreased annually from 14.5 in 2008 to $9.1 \%$ in 2013 (12). This study showed that this substantial group of patients should not be underestimated. Similarly, we found that the frequency of inappropriate ASA use was $14 \%$ in our study population. The main EuroSCORE value in the inappropriate and appropriate groups was $4.6 \pm 2.6$ and $13.2 \pm 5.3$, respectively. The difference in the EuroSCORE values was related with age, systolic blood pressure and lipid parameter levels in patients of inappropriate group.

\begin{tabular}{|c|c|c|c|c|}
\hline & $\begin{array}{l}\text { Inappropriate use } \\
(n=102)\end{array}$ & $\begin{array}{l}\text { Appropriate use } \\
(\mathrm{n}=634)\end{array}$ & $\begin{array}{l}\text { Test value } \\
\chi^{2} \\
\end{array}$ & $p$ \\
\hline BARC $0, \mathrm{n}(\%)$ & $102(99.0)$ & $592(93.5)$ & 5.706 & 0.222 \\
\hline BARC $2, \mathrm{n}(\%)$ & $0(0.0)$ & $29(4.6)$ & - & - \\
\hline BARC $3 a, n(\%)$ & $1(1.0)$ & $8(1.3)$ & - & - \\
\hline BARC 3b, n (\%) & $0(0.0)$ & $2(0.3)$ & - & - \\
\hline BARC 3c, n (\%) & $0(0.0)$ & $2(0.3)$ & - & - \\
\hline Delta hemoglobin $3 \mathrm{~g} / \mathrm{dL}$ above, $\mathrm{n}(\%)$ & $7(13.5)$ & $54(13.4)$ & 0.00 & 0.99 \\
\hline Delta hemoglobin $5 \mathrm{~g} / \mathrm{dL}$ above, $\mathrm{n}(\%)$ & $1(1.9)$ & $6(1.5)$ & 0.057 & 0.575 \\
\hline
\end{tabular}


The patients in the inappropriate group were younger and their systolic blood pressure and total and HDL levels were lower compared to appropriate primary prevention group. There was a significant difference in BMI between the three groups and all the patients in the groups were overweight. Especially inappropriate group had the highest mean BMI value which was $29.3 \pm 5.8 \mathrm{~kg} / \mathrm{m}^{2}$. Our data also showed that ASA was prescribed by physicians in $94.1 \%$ of patients and only $5.9 \%$ of participants were receiving ASA on their own.

Our study data clearly revealed that the most common reason for inappropriate ASA use was hypertension $(35.3 \%)$. ASA use in hypertension is a matter of concern for being associated with increased risk for bleeding events with uncontrolled blood pressure levels which might cast a shadow on possible beneficial effects in prevention of cardiovascular (CV) events. It has been shown in the hypertension optimal treatment trial that the addition of low-doses ASA to blood pressure lowering therapy had no beneficial effect (15). It had been well known that the prevalence of uncontrolled hypertension is higher than controlled hypertension all over the world. It has been reported that the overall age-adjusted prevalence of blood pressure control in the U.S. during 2007-2010 was $48.0 \%$ (16). In Turkey, this rate has been reported to be only $8.1 \%$ in 2003 (17). Therefore, individual risk assessment for benefits or harms should be done for each patient.

Second common reason for starting ASA was coronary angiography even though the results were normal. A recently published trial showed that ASA use in the presence of non obstructive coronary artery disease had no beneficial effect on survival (18). In $26.5 \%$ of patients, the reason for inappropriate ASA use was normal coronary angiography results. All these cases had major CV risk factors such as hypertension but their EuroSCORE value was low. In addition, using ASA with normal coronary angiography results did not increase the risk for major or minor bleeding events. Another controversial reason for ASA use in the literature is diabetes mellitus. In their meta-analysis of randomized controlled trials, Berardis et al. (19) found no clear benefit of ASA in the prevention of major CV events in patients with diabetes mellitus. On the other hand, ASA may increase the risk of Gl bleeding which may be higher in patients with diabetes. For middle aged diabetics, estimated Gl bleeding risk is 1 or 2 per 1000 and for those aged 70 years and older, it is $>5$ per 1000 in the overall population (20). In our study, diabetes mellitus was the reason for inappropriate ASA use in only, $11.9 \%$ of patients. Diabetes mellitus did not increase the risk for major or minor adverse events in patients receiving ASA inappropriately. There was no evidence of beneficial effect of starting ASA in patients with mild or moderate valvular heart disease (21). In our study only $9.8 \%$ of patients were receiving ASA for mild valvular heart disease. These patients had no adverse event during ASA therapy. Another reason for inappropriate ASA use was dysrhytmia with a same rate of valvular heart disease. Seventeen patients had permanent $A F$ in the study and the mean Chads 2 vasc score was $3.09 \pm 0.93$ and HAS-BLED score was $3 \pm 1.67$. Thus, all these AF patients had indication for oral anticoagulation. It was reasonable to start antiplatelet therapy in patients who refused to use any oral anticoagulant, although the evidence for effective stroke prevention with ASA in AF is weak (22). This group of patients was included in the group of appropriate use of ASA. They had one major and three minor bleeding events. Although this patient group had high bleeding scores, bleeding events did not reach statistical significance. ASA use in heart failure is another controversial topic. The common opinion in the literature is that it would be reasonable to suggest that ASA had beneficial effect in patients with underlying $C A D$, on the other hand, its benefit for patients with no evidence of coronary or other atherosclerotic vascular disease is still unknown (23). There is no clear evidence for beneficial effect ASA use for patients with non-ischemic heart failure. General belief in this issue is that there is no role for routine use of ASA in patients with nonischemic cardiomyopathy (24). In our study population, there were seven patients with nonischemic heart failure with sinus rhythm. They also had no adverse event during the ASA therapy period. There is no direct comparison of the benefit of using ASA in patients with isolated dyslipidemia. Patients with dyslipidemia, as well as other risk factors, should be evaluated with estimated risk score models. In our study, we had four patients with dyslipidemia and three with hypertension and dyslipidemia in the low-risk group. These patients had no adverse bleeding event. There are limited data about PPI use for decreasing the risks of Gl bleeding events in patients on long-term ASA therapy. PPIs had potential benefit of decreasing low-dose ASA-associated upper GI ulcers and bleeding events (25). In our study groups, the rate of concomitant PPI use was $41.9 \%, 57.4 \%$ and $46.6 \%$, respectively, but these levels did not affect Gl bleeding event rates.

ASA and NSAIDs are known to increase the risk of GI bleeding. Concurrent use of ASA and NSAID further increases the risk of bleeding (26). Approximately half of our study population was using NSAIDs, but it was not 
associated the increased risk of $\mathrm{Gl}$ bleeding. Patients of primary prevention groups were using NSAIDs more than those of secondary prevention group. The total number of drugs used by the patients in inappropriate use group was fewer than in the others. However, the total number of drugs was not related to increased risk of minor or major bleeding in the study population.

Lastly, in almost half of women, hemoglobin levels revealed anaemia but these rates were not found to be significantly different between the groups. The rate of males with anaemia was the lowest in inappropriate group than in the others. It seems that patients who had a vascular event might be more prone to anaemia during ASA therapy. On the other hand, $13 \%$ of our study group had experienced $3 \mathrm{gr} / \mathrm{dL}$ hemoglobin drop during ASA therapy. It has been reported that anaemia was independently associated with an increased risk of CVD even in healthy individuals (27). Despite all these reported negative effects of ASA, our study results showed that there was no difference in minor and major bleeding event rates between the groups.

\section{Study Limitations}

The major limitation is the small sample size which might have decreased the power of our study. The study participants were recruited from our outpatient clinics only, therefore, we could only evaluate non-fatal bleeding outcomes. The frequency of non-fatal major bleeding was low; thus, it did not reach statistical significance in all groups. We did not evaluate the ischeamic outcomes of patients because of the study design.

\section{Conclusion}

Our results show that an important number of patients were using ASA inappropriately for primary prevention of CVD. It could be possible to consider that inappropriate use of ASA did not increase non-fatal major and minor bleeding events. Nevertheless, our results should be supported by prospective clinical trials.

\section{Authorship Contributions}

Concept: M.Ö., O.E.T. Design: M.Ö., O.E.T. Data Collection or Processing: M.Ö., O.E.T. Analysis or Interpretation: M.Ö., O.E.T. Literature Search: M.Ö., O.E.T. Writing: M.Ö., O.E.T.

Conflict of Interest: The authors declared that there is no conflict of interest regarding the publication of this paper.

Financial Disclosure: The authors declared that this study received no financial support.

\section{References}

1. Hennekens $\mathrm{CH}$, Dyken ML, Fuster V. Acetylsalicylic acid as a therapeutic agent in cardiovascular disease: a statement for healthcare professionals from the American Heart Association. Circulation 1997;96:2751.

2. TUiK 2016: Ölüm istatistikleri. Sayı: 21526.

3. Warner TD, Mitchell JA. Cyclooxygenase-3 (COX-3): Filling in the gaps toward a COX continuum? Proc Natl Acad Sci U S A 2002;99:13371-3.

4. Antithrombotic Trialists' Collaboration. Collaborative metaanalysis of randomised trials of antiplatelet therapy for prevention of death, myocardial infarction, and stroke in high risk patients. BMJ 2002;324:71-86.

5. Hayden M, Pignone M, Phillips C, Mulrow C. Acetylsalicylic acid for the primary prevention of cardiovascular events: a summary of the evidence for the U.S. Preventive Services Task Force. Ann Intern Med 2002;136:161-72.

6. Nikolsky E, Stone GW, Kirtane AJ, et al. Gastrointestinal Bleeding in Patients With Acute Coronary Syndromes: Incidence, Predictors, and Clinical Implications: Analysis From the ACUITY (Acute Catheterization and Urgent Intervention Triage Strategy) Trial. J Am Coll Cardiol 2009;54:1293-302.

7. Huynh T, The'roux P, Bogaty $P$, Nasmith J, Solymoss S. Acetylsalicylic acid, warfarin, or the combination for secondary prevention of coronary events in patients with acute coronary syndromes and prior coronary artery bypass surgery. Circulation 2001;103:3069-74.

8. Massie BM, Collins JF, Ammon SE, et al. WATCH Trial Investigators. Randomized trial of warfarin, acetylsalicylic acid, and clopidogrel in patients with chronic heart failure: the Warfarin and Antiplatelet Therapy in Chronic Heart Failure (WATCH) trial. Circulation 2009;119:1616-24.

9. Piepoli MF, Hoes AW, Agewall S, et al. 2016 European Guidelines on cardiovascular disease prevention in clinical practice: The Sixth Joint Task Force of the European Society of Cardiology and Other Societies on Cardiovascular Disease Prevention in Clinical Practice (constituted by representatives of 10 societies and by invited experts): Developed with the special contribution of the European Association for Cardiovascular Prevention \& Rehabilitation (EACPR). Eur Heart J 2016.

10. Bibbins-Domingo K. U.S. Preventive Services Task Force. Acetylsalicylic acid Use for the Primary Prevention of Cardiovascular Disease and Colorectal Cancer: U.S. Preventive Services Task Force Recommendation Statement. Ann Intern Med 2016;164:836-45.

11. Whitlock EP, Burda BU, Williams SB, Guirguis-Blake JM, Evans CV. Bleeding risks with acetylsalicylic acid use for primary prevention in adults: a systematic review for the U.S. Preventive Services Task Force. Ann Intern Med 2016;164:826-35.

12. Hira RS, Kennedy K, Nambi V, et al. Frequency and PracticeLevel Variation in Inappropriate Acetylsalicylic acid Use for the Primary Prevention of Cardiovascular Disease. JACC 2015;65;111-21. 
13. Mehran R, Rao SV, Bhatt DL, et al. Standardized Bleeding Definitions for Cardiovascular Clinical Trials. Circulation 2011;123:2736-47.

14. World Health Organization. Haemoglobin Concentrations for the Diagnosis of Anaemia and Assessment of Severity. Vitamin and Mineral Nutrition Information Cystem; WHO, Geneva; Switzerland, 2011.

15. Hansson L, Zanchetti A, Carruthers SG, et al. Eff ects of intensive blood-pressure lowering and low-dose acetylsalicylic acid in patients with hypertension: principal results of the Hypertension Optimal Treatment (HOT) randomised trial. Lancet 1998;351:1755-62.

16. Gillespie $C D$, Hurvitz KA. Prevalence of Hypertension and Controlled Hypertension - United States, 2007-2010. MMWR Suppl 2013;62:144-8.

17. Altun B, Arici M, Nergizoğlu G, et al; for the Turkish Society of Hypertension and Renal Diseases. Prevalence, awareness, treatment and control of hypertension in Turkey (the PatenT study) in 2003. J Hypertens 2005;23:1817-23.

18. Chow BJW, Small G, Yam Y, et al. Prognostic and Therapeutic Implications of Statin and Acetylsalicylic acid Therapy in Individuals With Nonobstructive Coronary Artery Disease Results From the CONFIRM (Coronary CT Angiography Evaluation For Clinical Outcomes: An International Multicenter Registry) Registry. Arterioscler Thromb Vasc Biol 2015;35:981-9.

19. Berardis G, Sacco M, Strippoli GFM, et al. Acetylsalicylic acid for primary prevention of cardiovascular events in people with diabetes: meta-analysis of randomised controlled trials. BMJ 2009;339:b4531.

20. S. Derry YK. Loke Risk of gastrointestinal haemorrhage with long term use of acetylsalicylic acid: meta-analysis BMJ 2000;321:1183-7.
21. Vahanian A, Alfieri $O$, Andreotti $F$, et al. Guidelines on the management of valvular heart disease (version 2012). Eur Heart J 2012;33:2451-96.

22. Camm AJ, Lip GY, De Caterina R, et al. 2012 focused update of the ESC Guidelines for the management of atrial fibrillation: an update of the 2010 ESC Guidelines for the management of atrial fibrillation - developed with the special contribution of the European Heart Rhythm Association. Europace 2012;14:1385-413.

23. Bermingham $M$, Shanahan MK, $O^{\prime}$ Connell $E$, et al. Acetylsalicylic acid Use in Heart Failure: Is Low-Dose Therapy Associated With Mortality and Morbidity Benefits in a Large Community Population? Circ Heart Fail 2014;7:243-50.

24. Bettari L, Fiuzat M, Becker R, Fekler M, Metra M, O'Connor CM. Thromboembolism and Antithrombotic Therapy in Patients With Heart Failure in Sinus Rhythm Current Status and Future Directions. Circ Heart Fail 2011;4:361-8.

25. Tran-Duy A, Vanmolkot FH, Joore MA, Hoes AW, Stehouwer CD. Should Patients Prescribed Long-term Low-Dose Acetylsalicylic acid Receive Proton Pump Inhibitors? A Systematic Review and Meta-analysis. Int J Clin Pract 2015;69:1088-111.

26. Mellemkjaer L, Blot WJ, Sørensen HT, et al. Upper gastrointestinal bleeding among users of NSAIDs: a population-based cohort study in Denmark. $\mathrm{Br} J$ Clin Pharmacol 2002;53:173-81.

27. Sarnak MJ, Tighiouart H, Manjunath G, et al. Anaemia as a risk factor for cardiovascular disease in The Atherosclerosis Risk in Communities (ARIC) study. J Am Coll Cardiol 2002;40:27-33. 